Key Words: Cesium

Tank Farm

Organic

Retention: Permanent

\title{
Reducing the Detection Limit for Tetraphenylborate in Tank 50H Waste
}

\author{
T. L. White \\ K. B. Martin \\ L. N. Oji \\ W. R. Wilmarth
}

March 10, 2004

Westinghouse Savannah River Company

Savannah River Site

Aiken, SC 29808

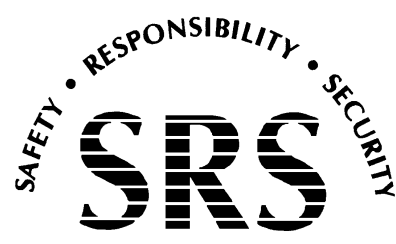

SAVANNAH RIVER SITE

Prepared for the U.S. Department of Energy Under

Contract Number DE-AC09-96SR18500 
This document was prepared in conjunction with work accomplished under Contract No. DE-AC09-96SR18500 with the U. S. Department of Energy.

\section{DISCLAIMER}

This report was prepared as an account of work sponsored by an agency of the United States Government. Neither the United States Government nor any agency thereof, nor any of their employees, makes any warranty, express or implied, or assumes any legal liability or responsibility for the accuracy, completeness, or usefulness of any information, apparatus, product or process disclosed, or represents that its use would not infringe privately owned rights. Reference herein to any specific commercial product, process or service by trade name, trademark, manufacturer, or otherwise does not necessarily constitute or imply its endorsement, recommendation, or favoring by the United States Government or any agency thereof. The views and opinions of authors expressed herein do not necessarily state or reflect those of the United States Government or any agency thereof.

This report has been reproduced directly from the best available copy.

Available for sale to the public, in paper, from: U.S. Department of Commerce, National Technical Information Service, 5285 Port Royal Road, Springfield, VA 22161, phone: (800) 553-6847, fax: (703) 605-6900

email: orders@ntis.fedworld.gov

online ordering: http://www.ntis.gov/help/index.asp

Available electronically at http://www.osti.gov/bridge

Available for a processing fee to U.S. Department of Energy and its contractors, in paper, from: U.S. Department of Energy, Office of Scientific and Technical Information, P.O. Box 62, Oak Ridge, TN 37831-0062,

phone: (865)576-8401,

fax: (865)576-5728

email: $\underline{\text { reports@ adonis.osti.gov }}$ 
This page was intentionally left blank 


\section{TABLE OF CONTENTS}

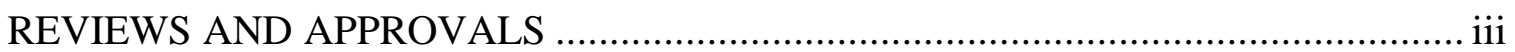

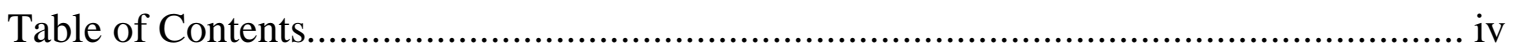

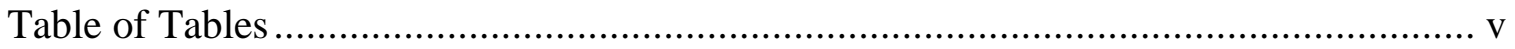

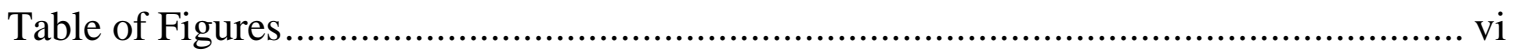

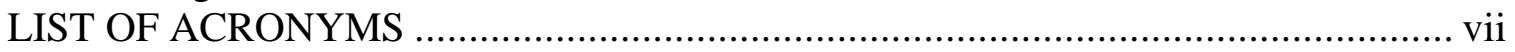

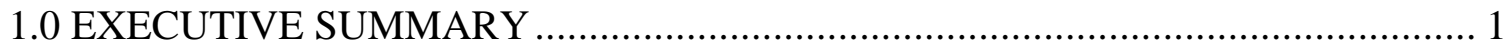

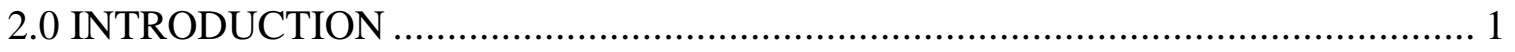

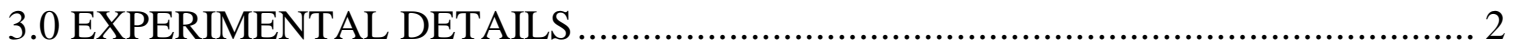

3.1 Preparation of 5.6 M Average Salt Solution ................................................ 3

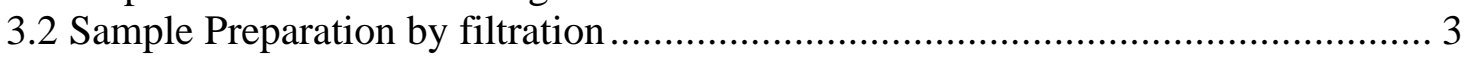

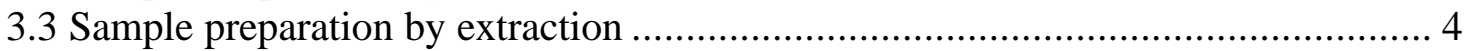

3.3.1 Simulated Waste Extraction....................................................................... 4

3.3.2 Dry Tank 50H Solids in Average Salt Solution............................................. 5

3.3.3 Dry Tank 50H Solids in Tank 41H Supernate and Plant Inhibited Water ........ 5

3.3.4 Blind Standards in Tank 41H and Plant Inhibited Water ................................. 6

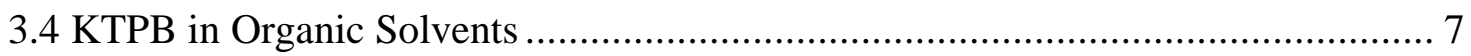

3.5 acetonitrile top layer in average salt solution ..................................................... 8

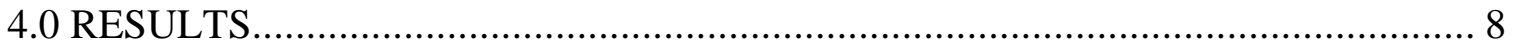

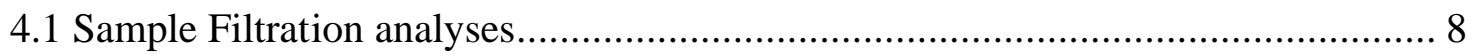

4.2 Sample extraction analyses......................................................................... 9

4.2.1 HPLC Analysis of TPB Spiked 5.6 M Average Salt Solution.......................... 9

4.2.2 HPLC Analysis of Tank 50H Solids in 5.6 M Average Salt Solution ............ 10

4.2.3 HPLC Analysis of Dry Tank 50H Solids in Tank 41H Supernate and PIW ... 11

4.2.4 HPLC Analysis of KTPB in Tank 41H and PIW...................................... 12

4.3 Gamma analysis of Extraction layers............................................................... 14

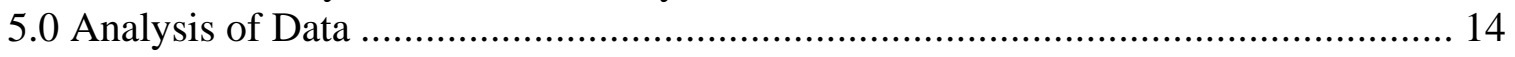

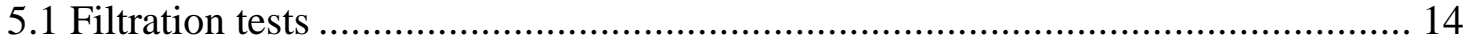

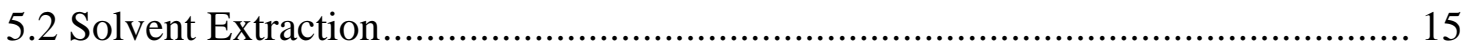

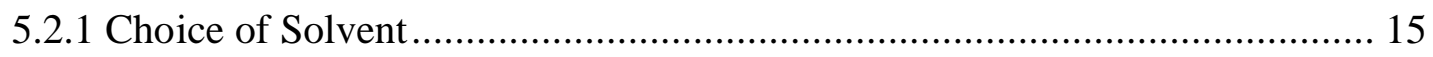

5.2.2 TPB Spiked 5.6 M Average Salt Solution..................................................... 16

5.2.3 Tank 50H solids in Average Salt Solution ………..................................... 17

5.2.4 Tank 50H solids in Tank 41H supernate and PIW...................................... 17

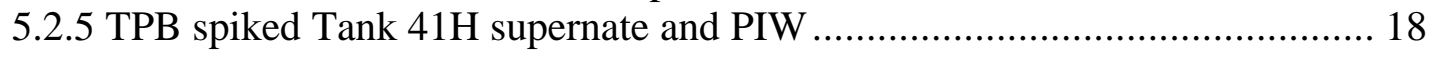

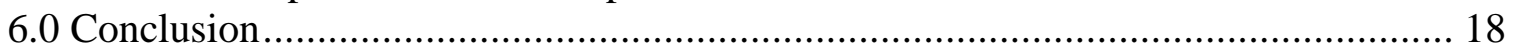

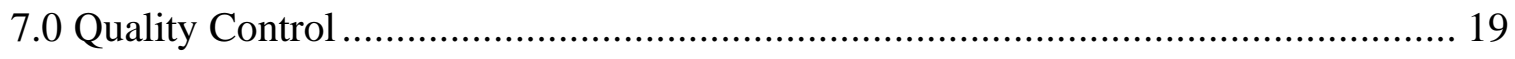

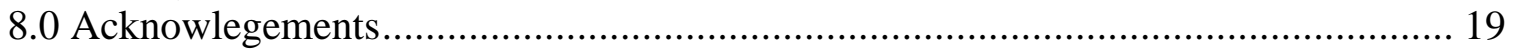

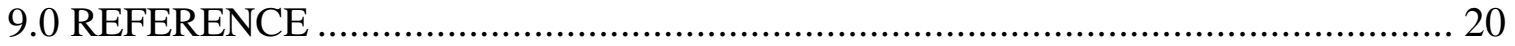




\section{TABLE OF TABLES}

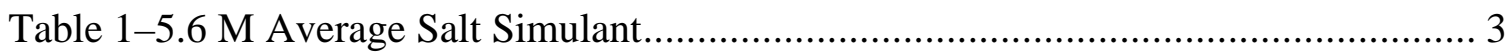

Table 2-Samples for Filtration Test ...................................................................... 4

Table 3-Acetonitrile Extraction of TPB Spiked 5.6 M Average Salt Solution .................. 5

Table 4-Weight of Dry Tank 50H Solids Added to Simulant .......................................... 5

Table 5-Weight of Dry Tank 50H Solids Added to Radioactive Simulant........................ 6

Table 6-Samples Analyzed Containing Tank 41H Supernate......................................... 6

Table 7-Weights of Solution Addition Performed in the Shielded Cells .......................... 7

Table 8-Solubility of KTPB in Various Solvents ....................................................... 8

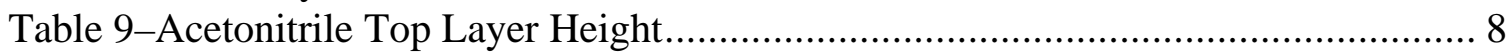

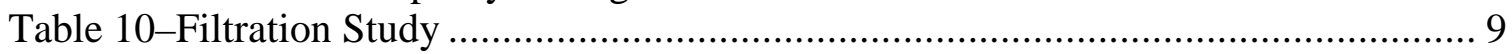

Table 11-TPB Spiked 5.6 M Average Salt Solution.................................................. 10

Table 12-Summary of HPLC Results ..................................................................... 11

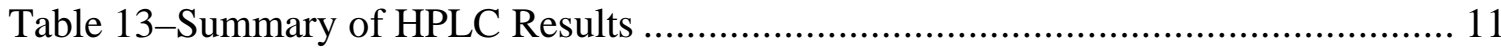

Table 14-KTPB in Tank 41H Supernate and PIW..................................................... 12

Table 15-Gamma Analysis of Top and Bottom Extraction Layers ................................. 14

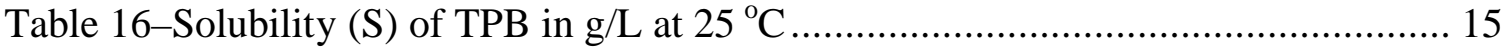




\section{TABLE OF FIGURES}

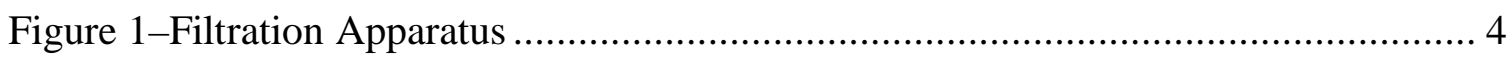

Figure 2-Vials and Mixed Used in Shielded Cells ....................................................... 7

Figure 3-Acetone Above 5.6 M Average Salt Solution ................................................ 8

Figure 4-TPB HPLC Instrument Calibration Curve for Filtering Study.......................... 9

Figure 5-TPB HPLC Instrument Calibration Curve for Extraction Study...................... 10

Figure 6-TPB HPLC Instrument Calibration Curve for Radioactive Extraction Study .. 12

Figure 7-Standards Prepared in the Shielded Cell .................................................... 13

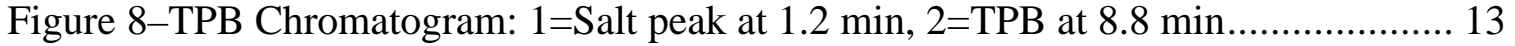

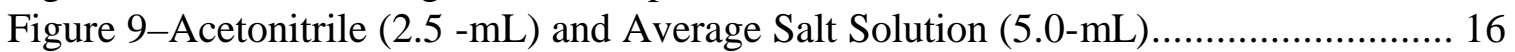

Figure 10-TPB Spiked into Average Salt Solution.................................................. 17 


\section{LIST OF ACRONYMS}

$\begin{array}{ll}\text { KTPB } & \text { Potassium tetraphenylborate }-\mathrm{K}\left[\mathrm{B}\left(\mathrm{C}_{6} \mathrm{H}_{5}\right)\right]_{4} \\ \text { CsTPB } & \text { Cesium tetraphenylborate }\left(\mathrm{Cs}\left[\mathrm{B}\left(\mathrm{C}_{6} \mathrm{H}_{5}\right)_{4}\right]\right) \\ \text { TPB } & \text { Tetraphenylborate }-\left[\mathrm{B}\left(\mathrm{C}_{6} \mathrm{H}_{5}\right)_{4}\right]^{-} \\ \text {NaTPB } & \text { Sodium tetraphenylborate }-\mathrm{Na}\left[\mathrm{B}\left(\mathrm{C}_{6} \mathrm{H}_{5}\right)_{4}\right] \\ \text { HPLC } & \text { High Performance Liquid Chromatography } \\ \text { PIW } & \text { Plant Inhibited Water } \\ \text { SD } & \text { Standard Deviation } \\ \text { RSD } & \text { Relative Standard Deviation } \\ \sigma \% \text { unc. } & \text { One Sigma Percent Uncertainty } \\ \text { ADS } & \text { Analytical Development Section } \\ \text { SRTC } & \text { Savannah River Technology Center } \\ \text { WPTS } & \text { Waste Processing Technology Section } \\ \text { ADS } & \text { Analytical Development Section } \\ \text { FW } & \text { Formula Weight } \\ \text { MW } & \text { Molecular Weight } \\ \mathrm{K}_{\mathrm{D}} & \text { Distribution or Partition Coefficient }=\mathrm{C}_{2} / \mathrm{C}_{1} \\ \mathrm{C}_{2} & \text { Concentration of Substance in Solvent } 2 \text { in } \mathrm{g} / \mathrm{L} \\ \mathrm{C}_{1} & \text { Concentration of Substance in Solvent } 1 \text { in } \mathrm{g} / \mathrm{L}\end{array}$


WSRC-TR-2004-00157, REV. 0

\subsection{EXECUTIVE SUMMARY}

A Technical Task Request SP-TTR-2003-00060 was issued that charged SRTC personnel with developing a technique that can determine the concentration of tetraphenylborate (TPB) at 300 grams in 100,000 gallons of salt solution $(0.8 \mathrm{mg} / \mathrm{L})$ in the presence of $0.378 \mathrm{Ci} / \mathrm{gal}$ of Cs-137. The current High Performance Liquid Chromatography (HPLC) method of analysis can determine the TPB concentration at $5 \mathrm{mg} / \mathrm{L}$ and higher. The limit of quantitation was lowered by modification of the sample preparation steps.

The HPLC sample preparation method currently used requires neutralization of the tank waste sample followed by extraction with acetonitrile. This method dilutes the tank waste sample 6.5 to 1 increasing the limit of quantitation. The method described in this report concentrates the sample two-fold lowering the limit of quantitation from $5 \mathrm{mg} / \mathrm{L}$ to 0.25 $\mathrm{mg} / \mathrm{L}$.

Researchers used solvent extraction of undiluted tank waste to isolate, and concentrate (two-fold) samples of Tank $41 \mathrm{H}$ supernate and Plant Inhibited Water (PIW) that simulated Tank $50 \mathrm{H}$ supernate at the cesium level of approximately $0.3 \mathrm{Ci} / \mathrm{gal}$. The ${ }^{137} \mathrm{Cs}$ content ${ }^{1}$ in the Tank $41 \mathrm{H}$ supernate measured $0.65 \mathrm{Ci} /$ gal prior to a two-fold dilution with PIW. The concentration of the TPB was determined by HPLC on a C18 reversed-phase HPLC column using methanol, acetonitrile, and $\mathrm{KH}_{2} \mathrm{PO}_{4}$ buffered water as the mobile phase.

\section{Important Findings}

- The $0.8 \mathrm{mg} / \mathrm{L}$ quantitation limit was met in the presence of radioactive cesium.

- A $93 \%$ reduction in activity in the acetonitrile layer was achieved. A five-mL acetonitrile aliquot from the extraction of a tank waste sample containing 0.378 $\mathrm{Ci} /$ gal of Cs-137 could be handled in a radiological hood and comply with the $<5$ $\mathrm{mR} / \mathrm{hr}$ hood limit.

- This method is applicable to tank waste solutions of high ionic strength $(>2.0 \mathrm{M}$ $\mathrm{Na}$ ). The ionic strength of tank waste solutions of low ionic strength will need to be adjusted by the addition of $\mathrm{NaOH}$ or $5.6 \mathrm{M}$ average salt solution to facilitate the formation of two layers (organic and aqueous). Increasing the ionic strength of tank waste samples by blending in a high ionic strength solution will raise the limit of quantitation.

\subsection{INTRODUCTION}

Tank $50 \mathrm{H}$ is scheduled to return to HLW Tank Farm service as a non-organic tank to receive decontaminated salt supernate from the Tank Farm. It serves as a staging tank for feed to the Saltstone Facility where liquid waste will be grouted for final disposal. Before returning Tank $50 \mathrm{H}$ to Tank Farm service, the Documented Safety Analysis (DSA) requires the organic content within the tank to be less than a 5\% contribution to the lower flammability limit (LFL). In October of 2002, camera inspections in Tank 50H revealed two large mounds of solid material, one in the vicinity of the B5 Riser Transfer Pump and the other on the opposite side of the tank. ${ }^{2}$ Personnel sampled and analyzed this material 
to determine its composition. ${ }^{3}$ The sample analysis indicated the presence of a significant quantity of organics in the solid material. The quantity of organic material exceeds the limit for declaring only trace amounts of organic material remain in Tank $50 \mathrm{H}$. Additionally, these large volumes of solids, calculated ${ }^{4}$ as approximately $61 \mathrm{~K}$ gallons, causes concern for potential generation of flammable gases and nuclear criticality safety implications. The minimum allowable amount of TPB that may remain in Tank $50 \mathrm{H}$ at a specified probe height of 367 inches and meeting the DSA prescribed 5\% LFL limit was calculated to be $0.8 \mathrm{mg} / \mathrm{L} .^{5}$

Researchers determined tetraphenylborate (TPB) concentrations using a HPLC instrument that isolates the analyte using reversed-phase column chromatography and quantitate the analyte with a diode-array ultra-violet (UV) detector. Investigators examined two sample preparation methods for increasing sensitivity of the analytical technique: filtration and solvent extraction.

\section{Application to Tank 48H}

The same need to measure low concentrations of phenylborate compounds exists for Tank $48 \mathrm{H}$. Tank $48 \mathrm{H}$ currently contains $\sim 250,000$ gallons of salt solution containing significant quantities of tetraphenylborate (TPB) salts. The TPB salts make the Tank $48 \mathrm{H}$ waste incompatible with the existing HLW treatment and disposition facilities. Consequently, there is no defined path for the disposition of the Tank $48 \mathrm{H}$ waste. However, due to the need for additional HLW storage, successful disposition of the material in Tank $48 \mathrm{H}$ and return of the tank to routine service have been identified as two critically needed activities. Based on the current plans, Tank $48 \mathrm{H}$ is scheduled to be returned to service by 2007. The current concentration of ${ }^{137} \mathrm{Cs}$ in Tank $48 \mathrm{H}$ is 1.72 $\mathrm{Ci} / \mathrm{gal}$ for the slurry (or $1.01 * 10^{9} \mathrm{dpm} / \mathrm{mL}$ ). ${ }^{6}$ Therefore, analyses for Tank $48 \mathrm{H}$ may involve approximately four-fold higher radioactivity concentrations. While the treatment method will result in dilution of the radioactivity, these concentrations will provide a greater challenge for the analytical method than occurred in Tank 50H. Hence, Tank $48 \mathrm{H}$ sample pretreatment may require dilution for radiological protection of workers.

Return to routine service requires removal or destruction of the tetraphenylborate to leave a residual quantity of less than $400 \mathrm{~g} .{ }^{7}$ Hence, the desired analytical quantification limit can be less than $0.4 \mathrm{mg} / \mathrm{L}$ in this matrix.

\subsection{EXPERIMENTAL DETAILS}

Personnel accomplished the Technical Task in three phases. Phase one of the task description examined possible methods and established accuracy, linearity and precision with $5.6 \mathrm{M}$ average salt solution. For each method, researchers examined filtration and extraction sample preparation methods in this phase. From the experimental results, the authors chose to use the solvent extraction sample preparation method in the next two phases. Phase two demonstrated the viability of recovering TPB from Tank $50 \mathrm{H}$ solids in simulated waste matrix using solvent extraction as the sample preparation method. In phase three the method was demonstrated using real waste from Tank $41 \mathrm{H}$ and inhibited water.

Page 2 of 20 


\subsection{PREPARATION OF 5.6 M AVERAGE SALT SOLUTION}

Personnel prepared $5.6 \mathrm{M}$ average salt solution ${ }^{10}$ with the concentration of the components as summarized in Table 1.

Table 1-5.6 M Average Salt Simulant

\begin{tabular}{|l|c|}
\hline Component & Concentration (M) \\
\hline Total $\mathrm{Na}$ & 5.60 \\
\hline Free $\mathrm{NaOH}$ & 1.91 \\
\hline $\mathrm{NaNO}_{3}$ & 2.14 \\
\hline $\mathrm{NaNO}_{2}$ & 0.52 \\
\hline $\mathrm{Na}_{2} \mathrm{SO}_{4}$ & 0.15 \\
\hline $\mathrm{Na}_{2} \mathrm{CO}_{3}$ & 0.16 \\
\hline $\mathrm{NaAlO}$ & 0.31 \\
\hline $\mathrm{NaCl}$ & 0.025 \\
\hline $\mathrm{NaF}$ & 0.032 \\
\hline $\mathrm{Na} \mathrm{HPO}_{4}$ & 0.010 \\
\hline $\mathrm{Na}_{2} \mathrm{C}_{2} \mathrm{O}_{4}$ & 0.008 \\
\hline $\mathrm{Na}_{2} \mathrm{SiO}_{3}$ & 0.004 \\
\hline $\mathrm{Na}_{2} \mathrm{MoO}_{4}$ & 0.0002 \\
\hline $\mathrm{KNO}_{3}$ & 0.015 \\
\hline $\mathrm{CsNO}_{3}$ & 0.00014 \\
\hline
\end{tabular}

\subsection{SAMPLE PREPARATION BY FILTRATION}

From the 5.6 M average salt solution, personnel prepared four 200-mL solutions in 250$\mathrm{mL}$ high density polyethylene bottles containing TPB at different concentration levels (Table 2). A $0.5 \mathrm{M}$ solution of $\mathrm{CsNO}_{3}$ was also prepared and stored in a labeled $500-\mathrm{mL}$ high density polyethylene bottle. Researchers sampled 20 -mL aliqouts from the stirred 200-mL simulated waste solutions and transferred the aliquots to $25-\mathrm{mL}$ glass vials containing $2-\mathrm{mL}$ of $0.5 \mathrm{M} \mathrm{CsNO}_{3}$ solution. The vials were sealed using Teflon ${ }^{\circledR}$ lined caps and shaken. Personnel used a Pall Corporation 150-mL polyphenylsulfone magnetic filter funnel to filter the samples through a $47 \mathrm{~mm} 0.4 \mu \mathrm{m}$ Whatman Nuclepore filter pad under vacuum. The funnel rested on a 1-L Erlenmeyer flask equipped with a side arm and mother liquor was collected in a test tube (Figure 1). After washing the vial and filter pad with 4.0-mL of 5.6 M average salt solution, personnel removed the filter pad and placed it in a $25-\mathrm{mL}$ glass vial containing $4-\mathrm{mL}$ of acetonitrile. Investigators placed Teflon ${ }^{\circledR}$ lined caps on the vials and immersed the vials in a sonication bath for 10 minutes. The acetonitrile was analyzed by HPLC (ADS-1601 procedure). Researchers expected a fivefold concentration of the samples as outlined below.

- 20-mL of sample $+2-\mathrm{mL} \mathrm{CsNO}_{3}$

- Collect all TPB in sample on filter pad

- Dissolve all TPB in 4-mL of acetonitrile

- $20-\mathrm{mL} / 4-\mathrm{mL}=5$ fold concentration 
WSRC-TR-2004-00157, REV. 0

Table 2-Samples for Filtration Test

\begin{tabular}{|c|c|c|}
\hline Sample & TPB conc. $\mu \mathrm{g} / \mathrm{mL}$ & Comments \\
\hline TPB/Simulant-0.6-1 & 0.6 & \multirow{3}{*}{$\begin{array}{l}\text { Spike } 0.012-\mathrm{mL} \text { of } 10,000 \\
\mathrm{mg} / \mathrm{L} \text { TPB }\end{array}$} \\
\hline TPB/Simulant-0.6-2 & 0.6 & \\
\hline TPB/Simulant-0.6-3 & 0.6 & \\
\hline TPB/Simulant-0.8-1 & 0.8 & \multirow{3}{*}{$\begin{array}{l}\text { Spike } 0.016-\mathrm{mL} \text { of } 10,000 \mathrm{mg} / \mathrm{L} \\
\text { TPB }\end{array}$} \\
\hline TPB/Simulant-0.8-2 & 0.8 & \\
\hline TPB/Simulant-0.8-3 & 0.8 & \\
\hline TPB/Simulant-2.0-1 & 2.0 & \multirow{3}{*}{$\begin{array}{l}\text { Spike } 0.040-\mathrm{mL} \text { of } 10,000 \mathrm{mg} / \mathrm{L} \\
\text { TPB }\end{array}$} \\
\hline TPB/Simulant-2.0-2 & 2.0 & \\
\hline TPB/Simulant-2.0-3 & 2.0 & \\
\hline TPB/Simulant-5.0-1 & 5.0 & \multirow{3}{*}{$\begin{array}{l}\text { Spike } 0.100-\mathrm{mL} \text { of } 10,000 \mathrm{mg} / \mathrm{L} \\
\text { TPB }\end{array}$} \\
\hline TPB/Simulant-5.0-2 & 5.0 & \\
\hline TPB/Simulant-5.0-3 & 5.0 & \\
\hline
\end{tabular}

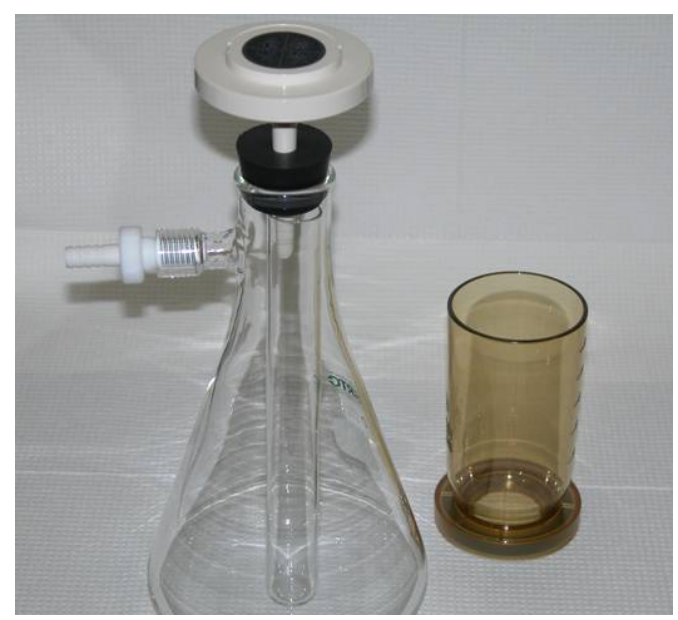

Figure 1-Filtration Apparatus

\subsection{SAMPLE PREPARATION BY EXTRACTION}

\subsubsection{Simulated Waste Extraction}

Personnel prepared twelve 5-mL 5.6 M average salt solution samples containing TPB at four different concentration levels (Table 3 ) in 16--mL vials with Teflon ${ }^{\circledR}$ insert caps. Researchers added $0.5-\mathrm{mL}$ of $0.5 \mathrm{M} \mathrm{CsNO}_{3}$ to the samples followed by $2.5-\mathrm{mL}$ of acetonitrile. Personnel mixed the solution for 5 minutes on a Vortex mixer, let the vials stand until two layers formed, and analyzed the top layer by HPLC. Analysts expected a two fold concentration $(5-\mathrm{mL}$ sample $/ 2.5-\mathrm{mL}$ acetonitrile $=2$-fold concentration). 
WSRC-TR-2004-00157, REV. 0

Table 3-Acetonitrile Extraction of TPB Spiked 5.6 M Average Salt Solution

\begin{tabular}{|c|c|c|}
\hline Sample & TPB conc. $\mu \mathrm{g} /-\mathrm{mL}$ & Comments \\
\hline TPB/Simulant-0.5-a & 0.5 & \multirow{3}{*}{$\begin{array}{l}\text { Spiked } 0.005-\mathrm{mL} \text { of } 500 \mathrm{mg} / \mathrm{L} \mathrm{TPB} \\
\text { in } 5.0-\mathrm{mL} \text { of } 5.6 \mathrm{M} \text { average salt sol. }\end{array}$} \\
\hline TPB/Simulant-0.5-b & 0.5 & \\
\hline TPB/Simulant-0.5-c & 0.5 & \\
\hline TPB/Simulant-1.0-a & 1.0 & \multirow{3}{*}{$\begin{array}{l}\text { Spiked } 0.01-\mathrm{mL} \text { of } 500 \mathrm{mg} / \mathrm{L} \mathrm{TPB} \text { in } \\
5.0-\mathrm{mL} \text { of } 5.6 \mathrm{M} \text { average salt sol. }\end{array}$} \\
\hline TPB/Simulant-1.0-b & 1.0 & \\
\hline TPB/Simulant-1.0-c & 1.0 & \\
\hline TPB/Simulant-2.0-a & 2.0 & \multirow{3}{*}{$\begin{array}{l}\text { Spiked } 0.02-\mathrm{mL} \text { of } 500 \mathrm{mg} / \mathrm{L} \mathrm{TPB} \text { in } \\
5.0-\mathrm{mL} \text { of } 5.6 \mathrm{M} \text { average salt sol. }\end{array}$} \\
\hline TPB/Simulant-2.0-b & 2.0 & \\
\hline TPB/Simulant-2.0-c & 2.0 & \\
\hline TPB/Simulant-5.0-a & 5.0 & \multirow{3}{*}{$\begin{array}{l}\text { Spiked } 0.05-\mathrm{mL} \text { of } 500 \mathrm{mg} / \mathrm{L} \mathrm{TPB} \text { in } \\
5.0-\mathrm{mL} \text { of } 5.6 \mathrm{M} \text { average salt sol. }\end{array}$} \\
\hline TPB/Simulant-5.0-b & 5.0 & \\
\hline TPB/Simulant-5.0-c & 5.0 & \\
\hline
\end{tabular}

\subsubsection{Dry Tank 50H Solids in Average Salt Solution}

Personnel prepared four samples of dry Tank $50 \mathrm{H}$ solids in $16-\mathrm{mL}$ vials with Teflon® insert caps (Table 4). Investigators added to three of the vials 5.0-mL of 5.6 M average salt solution and $0.5-\mathrm{mL}$ of $0.5 \mathrm{M} \mathrm{CsNO}_{3}$. After capping the vials, personnel mixed the three vials on a Vortex mixer. Researchers then added $2.5-\mathrm{mL}$ of acetonitrile to all four samples, capped the vials, mixed for five minutes on a Vortex mixer, let the vials stand until two layers formed, and analyzed the top layer by HPLC. Analysts expected a two fold concentration $(5-\mathrm{mL}$ sample/2.5-mL acetonitrile $=2$ fold concentration).

\section{Table 4-Weight of Dry Tank 50H Solids Added to Simulant}

\begin{tabular}{|l|l|}
\hline Sample & Weight of Dry Tank 50H Solids per Vial, $\mathbf{g}$ \\
\hline Tank 50H solids/simulated waste & 0.1042 \\
\hline Tank 50H solids/simulated waste & 0.1038 \\
\hline Tank 50H solids/simulated waste & 0.1033 \\
\hline Tank 50H solids & 0.0981 \\
\hline
\end{tabular}

\subsubsection{Dry Tank 50H Solids in Tank 41H Supernate and Plant Inhibited Water}

Personnel prepared four samples of dry Tank $50 \mathrm{H}$ solids in $20-\mathrm{mL}$ vials with Teflon® caps for the shielded cells (Table 5). Researchers added 5.0-mL of plant inhibited water (PIW) and $1.0-\mathrm{mL}$ of $0.5 \mathrm{M} \mathrm{CsNO}_{3}$ to the three vials and $5.0-\mathrm{mL}$ of acetonitrile to the forth vial. In the shielded cell, investigators added to the three vials containing PIW 5.0$\mathrm{mL}$ of Tank $41 \mathrm{H}$ supernate $(0.56 \mathrm{Ci} / \mathrm{gal})^{11}$. After capping the vials, personnel mixed the three vials on a Vortex mixer. Researches then added 5.0-mL of acetonitrile to the samples, capped the vials, mixed for five minutes on a Vortex mixer, let the vials stand until two layers formed, and transferred the solution to a vial shown in Figure 2 with a small inner diameter to make the top layer more pronounced. Researchers removed the top layer for TPB analysis and after an 11 -fold dilution of $0.5-\mathrm{mL}$ acetonitrile in $5.0-\mathrm{mL}$ PIW, for gamma scan (ADS-2420 procedure). Personnel removed and diluted 1.0-mL of 
the aqueous layer in 9-mL PIW for a 10-fold dilution. Researchers tracked the cell operations of the addition of Tank $41 \mathrm{H}$ and the addition of acetonitrile by weight as shown in

Table 7. Table 6 lists general information about the samples prepared in the shielded cells.

Table 5-Weight of Dry Tank 50H Solids Added to Radioactive Simulant

\begin{tabular}{|l|l|}
\hline Sample & Weight of Dry Tank 50H Solids per Vial, g \\
\hline Tank 50H solids/Tank 41H/PIW & 0.0982 \\
\hline Tank 50H solids/Tank 41H/PIW & 0.1014 \\
\hline Tank 50H solids/Tank 41H/PIW & 0.0994 \\
\hline Tank 50H solids & 0.1012 \\
\hline
\end{tabular}

Table 6-Samples Analyzed Containing Tank 41H Supernate

\begin{tabular}{|c|c|c|}
\hline Sample & Analyte & Comments \\
\hline Tank 50H Solids/Tank 41H Supernate/PIW & TPB & \multirow{3}{*}{$\begin{array}{l}\text { Compare to TPB analysis of } \\
\text { Tank 50H Solids/Average Salt } \\
\text { Solution }\end{array}$} \\
\hline Tank 50H Solids/Tank 41H Supernate/PIW & TPB & \\
\hline Tank 50H Solids/Tank 41H Supernate/PIW & TPB & \\
\hline KTPB/Tank 41H Supernate/PIW & TPB & \multirow{3}{*}{$\begin{array}{l}\text { Blind standards within the } \\
\text { range of } 0.6 \text { to } 5.0 \mathrm{mg} / \mathrm{L}\end{array}$} \\
\hline KTPB/Tank 41H Supernate/PIW & TPB & \\
\hline KTPB/Tank 41H Supernate/PIW & TPB & \\
\hline
\end{tabular}

\subsubsection{Blind Standards in Tank 41H and Plant Inhibited Water}

Personnel prepared three TPB standards and three TPB unknown samples of 5.0-mL of PIW and 1.0-mL of $0.5 \mathrm{M} \mathrm{CsNO}_{3}$ in 20 - $\mathrm{mL}$ vials with Teflon ${ }^{\circledR}$ caps for the shielded cells (Table 6). In the shielded cell, investigators added to the vials $5.0-\mathrm{mL}$ of Tank $41 \mathrm{H}$ supernate. After capping the vials, personnel mixed the three vials on a Vortex mixer. Researches then added 5.0-mL of acetonitrile to the samples, capped the vials, mixed for five minutes on a Vortex mixer, let the vials stand until two layers formed, and transferred the solution to a vial with a small inner diameter to make the top layer more pronounced (Figure 2). Personnel sampled the top layer for HPLC analysis. Researchers tracked the cell operations of the addition of Tank $41 \mathrm{H}$ and the addition of acetonitrile by weight as shown in

Table 7. Analysts expected a two-fold concentration (10-mL sample/5.0-mL acetonitrile $=2$-fold concentration) 
WSRC-TR-2004-00157, REV. 0

Table 7-Weights of Solution Addition Performed in the Shielded Cells

\begin{tabular}{|l|c|c|c|c|}
\hline & Tank 41H Supernate & Density & Acetonitrile & Density \\
\hline ID & Wt of 5-mL & & Wt of 5-mL & \\
\hline & $g$ & $g / m L$ & $g$ & $g / m L$ \\
\hline Std $1 \mathrm{mg} / \mathrm{L}$ & 6.95 & 1.390 & 3.928 & 0.786 \\
\hline Std 2 mg/L & 6.582 & 1.316 & 3.828 & 0.766 \\
\hline std 5 mg/L & 6.904 & 1.381 & 4.05 & 0.810 \\
\hline Unknown 1 & 6.909 & 1.382 & 3.909 & 0.782 \\
\hline Unknown 2 & 6.85 & 1.370 & 4.066 & 0.813 \\
\hline Unknown 3 & 6.751 & 1.350 & 3.836 & 0.767 \\
\hline TK50 solids 1 & 6.585 & 1.317 & 3.655 & 0.731 \\
\hline TK50 solids 2 & 6.798 & 1.360 & 3.843 & 0.769 \\
\hline TK50 solids 3 & 6.756 & 1.351 & 3.855 & 0.771 \\
\hline Sum & 61.08 & & 34.97 & \\
\hline Ave. & 6.787 & 1.357 & 3.886 & 0.777 \\
\hline Std dev $(\sigma)$ & 0.134 & 0.027 & 0.124 & 0.025 \\
\hline
\end{tabular}

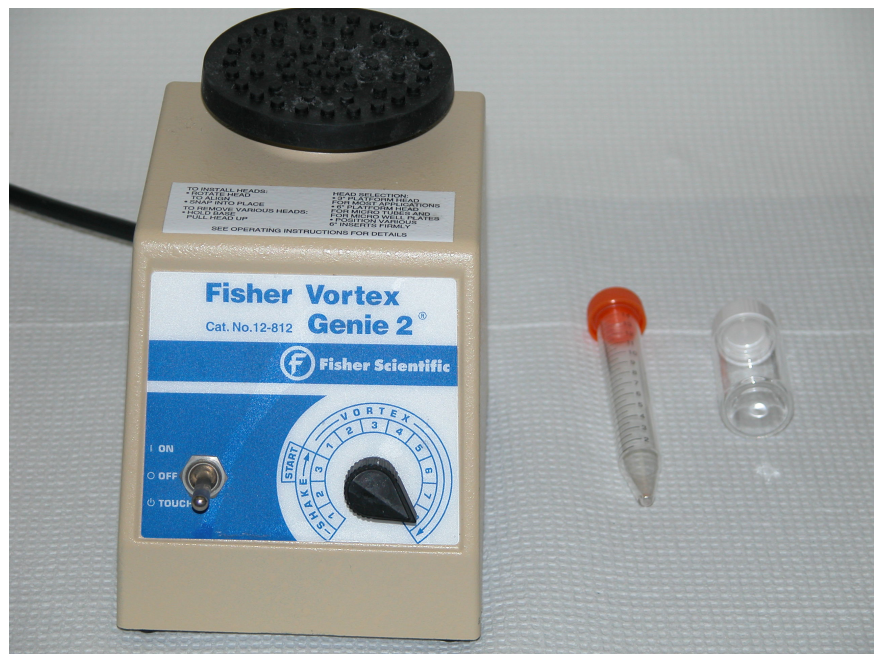

Figure 2-Vials and Mixed Used in Shielded Cells

\subsection{KTPB IN ORGANIC SOLVENTS}

In order to identify suitable extraction solvents, personnel examined the solubility of KTPB in chloroform, toluene, ethyl acetate, and acetonitrile as shown in Table 8. Researchers weighed $10 \mathrm{mg}$ of KTPB into $25-\mathrm{mL}$ vials, added solvent, capped the vials with Teflon ${ }^{\circledR}$ lined caps, immersed in a sonication bath for 10 minutes, and then examined the vial for solids. This process was repeated two more times. Researchers also added 10-mL of $5.6 \mathrm{M}$ average salt solution to two $16-\mathrm{mL}$ vial followed by the addition of $5-\mathrm{mL}$ of acetone to one vial and $5-\mathrm{mL}$ of acetonitrile to the other. Personnel capped the vial with Teflon ${ }^{\circledR}$ lined caps and let the solutions stand for one week. After one day, the 
top layer changed form clear to yellow and after a week the top layer became dark yellow as shown in Figure 3.

Table 8-Solubility of KTPB in Various Solvents

\begin{tabular}{|l|l|l|l|l|}
\hline Solvent & Chloroform & Toluene & Ethyl Acetate & Acetonitrile \\
\hline KTPB & $12.0 \mathrm{mg}$ & $11.2 \mathrm{mg}$ & $10.0 \mathrm{mg}$ & $14.0 \mathrm{mg}$ \\
\hline Vol. $5-\mathrm{mL}, 2000 \mathrm{mg} / \mathrm{L}$ & Not soluble & Not soluble & Not soluble & Soluble \\
\hline Vol. $10-\mathrm{mL}, 1000 \mathrm{mg} / \mathrm{L}$ & Not soluble & Not soluble & Not soluble & Soluble \\
\hline Vol. $20-\mathrm{mL}, 500 \mathrm{mg} / \mathrm{L}$ & Not soluble & Not soluble & Not soluble & Soluble \\
\hline
\end{tabular}

Figure 3-Acetone Above 5.6 M Average Salt Solution

\subsection{ACETONITRILE TOP LAYER IN AVERAGE SALT SOLUTION}

Personnel examined the height of the acetonitrile top layer as a function of aqueous salt concentration. Researchers added the volumes of materials listed in Table 9 to $16-\mathrm{mL}$ vials and recorded the top layer height.

Table 9-Acetonitrile Top Layer Height

\begin{tabular}{|r|c|c|c|c|c|c|}
\hline Vial \# & Ave SS, $\mathbf{~ m L}$ & $\mathbf{H}_{\mathbf{2}} \mathbf{0}, \mathbf{~} \mathbf{~ L}$ & $\mathbf{0 . 5} \mathbf{M} \mathbf{C s N O}_{\mathbf{3}}, \mathbf{~} \mathbf{m L}$ & $\mathbf{A C N}, \mathbf{m L}$ & $\mathbf{N a}, \mathbf{M}$ & Height, $\mathbf{~ m m}$ \\
\hline 1 & 0 & 0 & 0 & 2.5 & 0 & 9 \\
\hline 2 & 5 & 0 & 0.5 & 2.5 & 5 & 8 \\
\hline 3 & 4 & 1 & 0.5 & 2.5 & 4 & 7 \\
\hline 4 & 3 & 2 & 0.5 & 2.5 & 3 & 6 \\
\hline 5 & 2 & 3 & 0.5 & 2.5 & 2 & 4 \\
\hline 6 & 1 & 4 & 0.5 & 2.5 & 1 & No top layer \\
\hline
\end{tabular}

\subsection{RESULTS}

ADS personnel completed the HPLC (ADS-1601 procedure) and gamma analyses (ADS2420 procedure) between February 30, and March 09, 2003. The results are reported in this section and discussed in section 5.0, Analysis of Data.

\subsection{SAMPLE FILTRATION ANALYSES}

ADS personnel analyzed samples prepared by the sample preparation method described in section 3.2 by HPLC. Table 10 summarizes the results and the calibration curve is Figure 4. This method yielded poor recoveries that improved as the TPB concentration increased in the sample. 
Table 10-Filtration Study

\begin{tabular}{|c|c|c|}
\hline Sample & TPB conc., mg/L & Comments \\
\hline TPB/Simulant-0.6-1 & 0.2 & \multirow{3}{*}{$\begin{array}{l}\text { Expected: } 3 \mathrm{mg} / \mathrm{L} \\
\text { Average: } 0.27 \mathrm{mg} / \mathrm{L} \\
\% \text { recovery: } 9\end{array}$} \\
\hline TPB/Simulant-0.6-2 & 0.34 & \\
\hline TPB/Simulant-0.6-3 & Not Detected & \\
\hline TPB/Simulant-0.8-1 & Interference & \multirow{3}{*}{$\begin{array}{l}\text { Expected: } 4 \mathrm{mg} / \mathrm{L} \\
\text { Average: } 0.14 \mathrm{mg} / \mathrm{L} \\
\% \text { recovery: } 4\end{array}$} \\
\hline TPB/Simulant-0.8-2 & Interference & \\
\hline TPB/Simulant-0.8-3 & 0.14 & \\
\hline TPB/Simulant-2.0-1 & 0.6 & \multirow{3}{*}{$\begin{array}{l}\text { Expected: } 10 \mathrm{mg} / \mathrm{L} \\
\text { Average: } 0.73 \mathrm{mg} / \mathrm{L} \text { (\%rsd: } 18) \\
\% \text { recovery: } 7\end{array}$} \\
\hline TPB/Simulant-2.0-2 & 0.85 & \\
\hline TPB/Simulant-2.0-3 & 0.74 & \\
\hline TPB/Simulant-5.0-1 & 5.6 & \multirow{3}{*}{$\begin{array}{l}\text { Expected: } 25 \mathrm{mg} / \mathrm{L} \\
\text { Average: } 5.6 \mathrm{mg} / \mathrm{L} \text { (\%rsd: } 5.8 \text { ) } \\
\% \text { recovery: } 22\end{array}$} \\
\hline TPB/Simulant-5.0-2 & 6.0 & \\
\hline TPB/Simulant-5.0-3 & 5.3 & \\
\hline $\begin{array}{l}0.05 \mu \mathrm{m} \text { filtration of } \\
\text { mother liquor }\end{array}$ & 0.21 & $\begin{array}{l}\text { Remaining TPB anion in mother } \\
\text { liquor after } 0.4 \mu \mathrm{m} \text { filtration }\end{array}$ \\
\hline
\end{tabular}

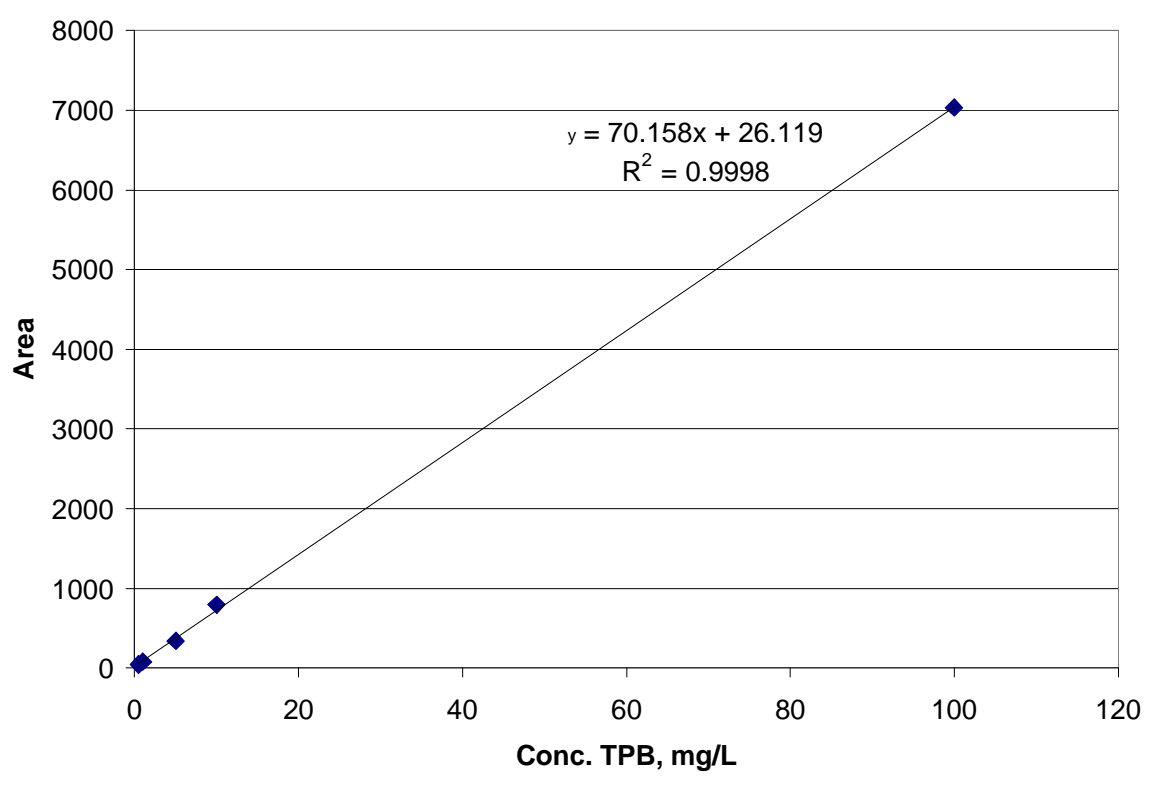

Figure 4-TPB HPLC Instrument Calibration Curve for Filtering Study

\subsection{SAMPLE EXTRACTION ANALYSES}

ADS personnel analyzed the acetonitrile layer from the extractions prepared as described in section 3.3. The main attributes of this sample preparation method are good recoveries and simplicity.

\subsubsection{HPLC Analysis of TPB Spiked 5.6 M Average Salt Solution}

Table 11 contains the results of the analyses of the samples prepared as described in 3.3.1 and Figure 5 is the calibration curve. The preparation method results in a two fold concentration of TPB in the acetonitrile layer. Researchers prepared in triplicate the 
average salt solutions with the concentrations of TPB at $0.5 \mathrm{mg} / \mathrm{L}, 1.0 \mathrm{mg} / \mathrm{L}, 2.0 \mathrm{mg} / \mathrm{L}$ and $5.0 \mathrm{mg} / \mathrm{L}$.

Table 11-TPB Spiked 5.6 M Average Salt Solution

\begin{tabular}{|c|c|c|c|c|}
\hline Expected Conc., mg/L & 10 & 4 & 2 & 1 \\
\hline & & & & \\
\hline Observed Conc., mg/L & 11.5 & 4.28 & 2.11 & 1.20 \\
\hline & 11.6 & 3.77 & 2.12 & 1.05 \\
\hline & 11.7 & 4.45 & 2.18 & 1.09 \\
\hline & & & & \\
\hline & 11.6 & 4.17 & 2.14 & 1.11 \\
\hline Average & 0.09 & 0.36 & 0.04 & 0.08 \\
\hline SD & 0.80 & 8.54 & 1.73 & 7.12 \\
\hline RSD(\%) & 5.0 & 20 & 2.8 & 6.0 \\
\hline$\sigma \%$ unc & 116 & 104 & 107 & 111 \\
\hline Recovery(\%) & \multicolumn{3}{|l}{} \\
\hline
\end{tabular}

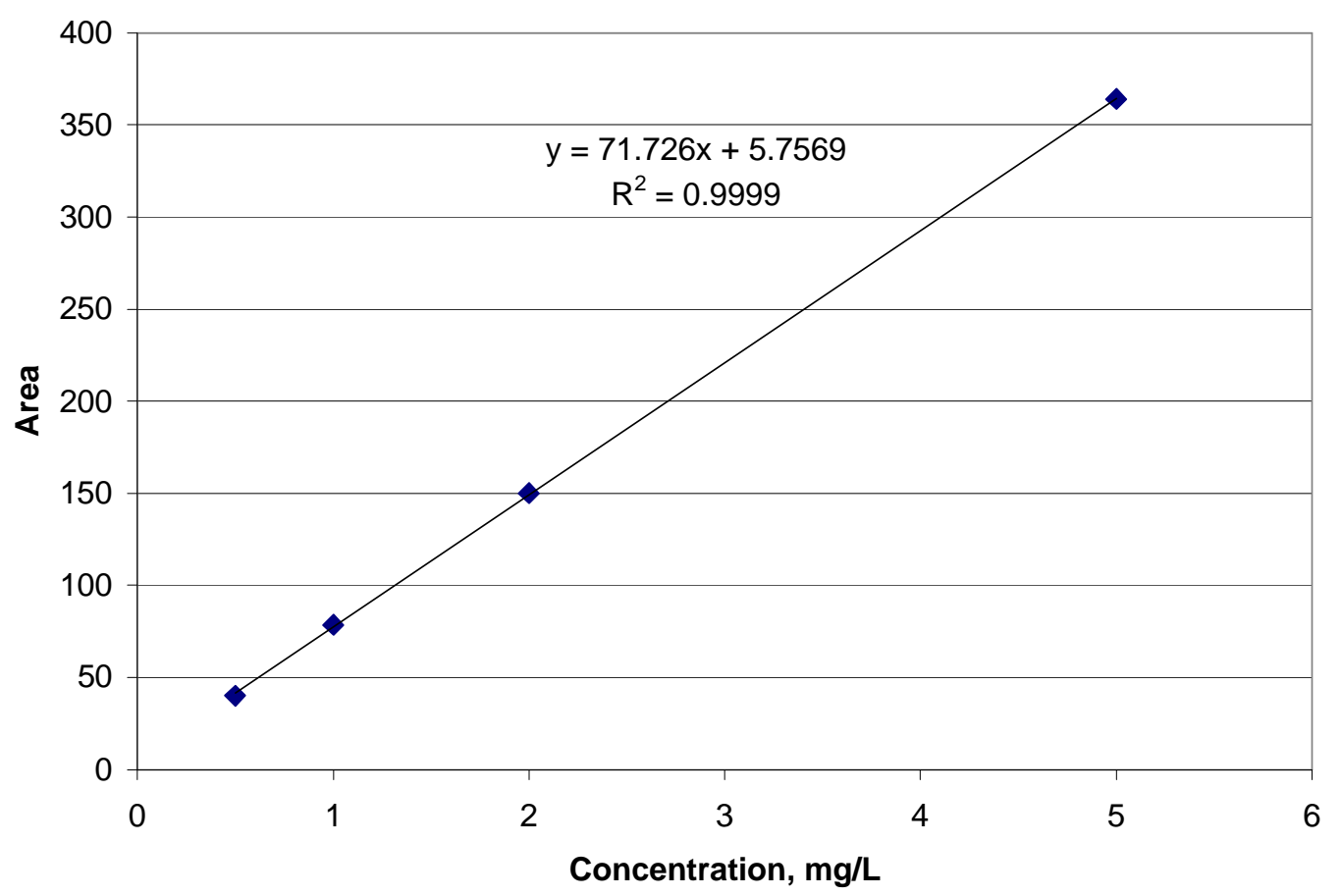

Figure 5-TPB HPLC Instrument Calibration Curve for Extraction Study

\subsubsection{HPLC Analysis of Tank 50H Solids in 5.6 M Average Salt Solution}

Table 12 contains the results of the analyses of the samples prepared as described in 3.3.2 and Figure 5 is the calibration curve. 
WSRC-TR-2004-00157, REV. 0

Table 12-Summary of HPLC Results

\begin{tabular}{|l|l|c|c|c|}
\hline Sample & Wt., g & Conc., mg/L & Conc, mg/Kg & Recovery(\%) \\
\hline Acetonitrile (ACN) only & 0.0981 & 11.4 & 291 & \\
\hline ACN/Average Salt Solution A & 0.1042 & 16 & 384 & 135 \\
\hline ACN/Average Salt Solution B & 0.1038 & 15.8 & 381 & 134 \\
\hline ACN/Average Salt Solution C & 0.1033 & 14.9 & 361 & 127 \\
\hline & & & & \\
\hline & Average & 15.6 & 375 & \\
\hline & RSD & 0.59 & 12.6 & \\
\hline & RSD(\%) & 0.04 & 0.03 & \\
\hline
\end{tabular}

\subsubsection{HPLC Analysis of Dry Tank 50H Solids in Tank 41H Supernate and PIW}

Table 13 contains the results of the analyses of the samples prepared as described in 3.3.3 and Figure 6 and Figure 7 are the calibration curves.

Table 13-Summary of HPLC Results

\begin{tabular}{|l|c|c|c|c|}
\hline Solids & Wt., g & $\begin{array}{l}\text { TPB in Solids, } \\
\mathbf{m g} / \mathbf{K g}\end{array}$ & $\begin{array}{l}\text { TPB in Extract, } \\
\mathbf{m g} / \mathbf{L}\end{array}$ & Recovery(\%) \\
\hline Tk50H solids/Tk41H supernate/PIW & 0.0982 & 146 & 2.86 & 106 \\
\hline Tk50H solids/Tk41H supernate/PIW & 0.1014 & 162 & 3.29 & 122 \\
\hline Tk50H solids/Tk41H supernate/PIW & 0.0994 & 181 & 3.59 & 133 \\
\hline Tk50H solids & 0.1012 & 133 & 2.70 & \\
\hline & & & & \\
\hline & Ave & 163 & 3.25 & \\
\hline & SD & 17.6 & 0.369 & \\
\hline & RSD $(\%)$ & 11 & 11 & \\
\hline
\end{tabular}


WSRC-TR-2004-00157, REV. 0

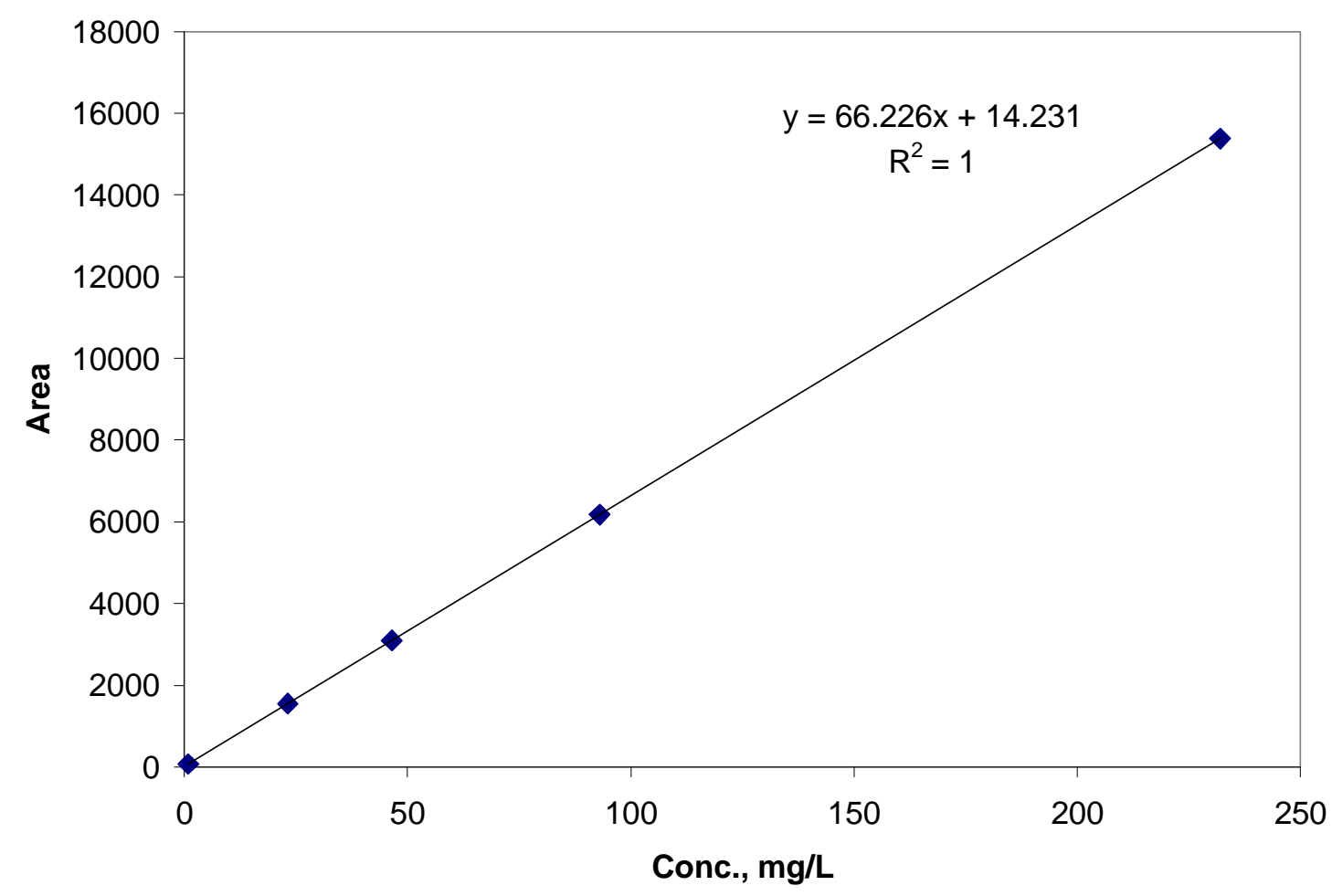

Figure 6-TPB HPLC Instrument Calibration Curve for Radioactive Extraction Study

\subsubsection{HPLC Analysis of KTPB in Tank 41H and PIW}

Table 14 contains the results of the HPLC analyses of the samples prepared as described in 3.3.4 and Figure 6 and Figure 3 are the calibration curves. Figure 8 is a chromatogram of Unknown 2 in Table 14.

Table 14-KTPB in Tank 41H Supernate and PIW

\begin{tabular}{|c|c|}
\hline Sample & Conc., mg/L \\
\hline Spike (3X) & 2.00 \\
\hline & \\
\hline Unknown 1 & 2.02 \\
\hline Unknown 2 & 1.99 \\
\hline Unknown 3 & 2.28 \\
\hline & \\
\hline Average & 2.10 \\
\hline SD & 0.16 \\
\hline RSD $(\%)$ & 7.61 \\
\hline$\sigma \%$ unc & 14.0 \\
\hline
\end{tabular}


WSRC-TR-2004-00157, REV. 0

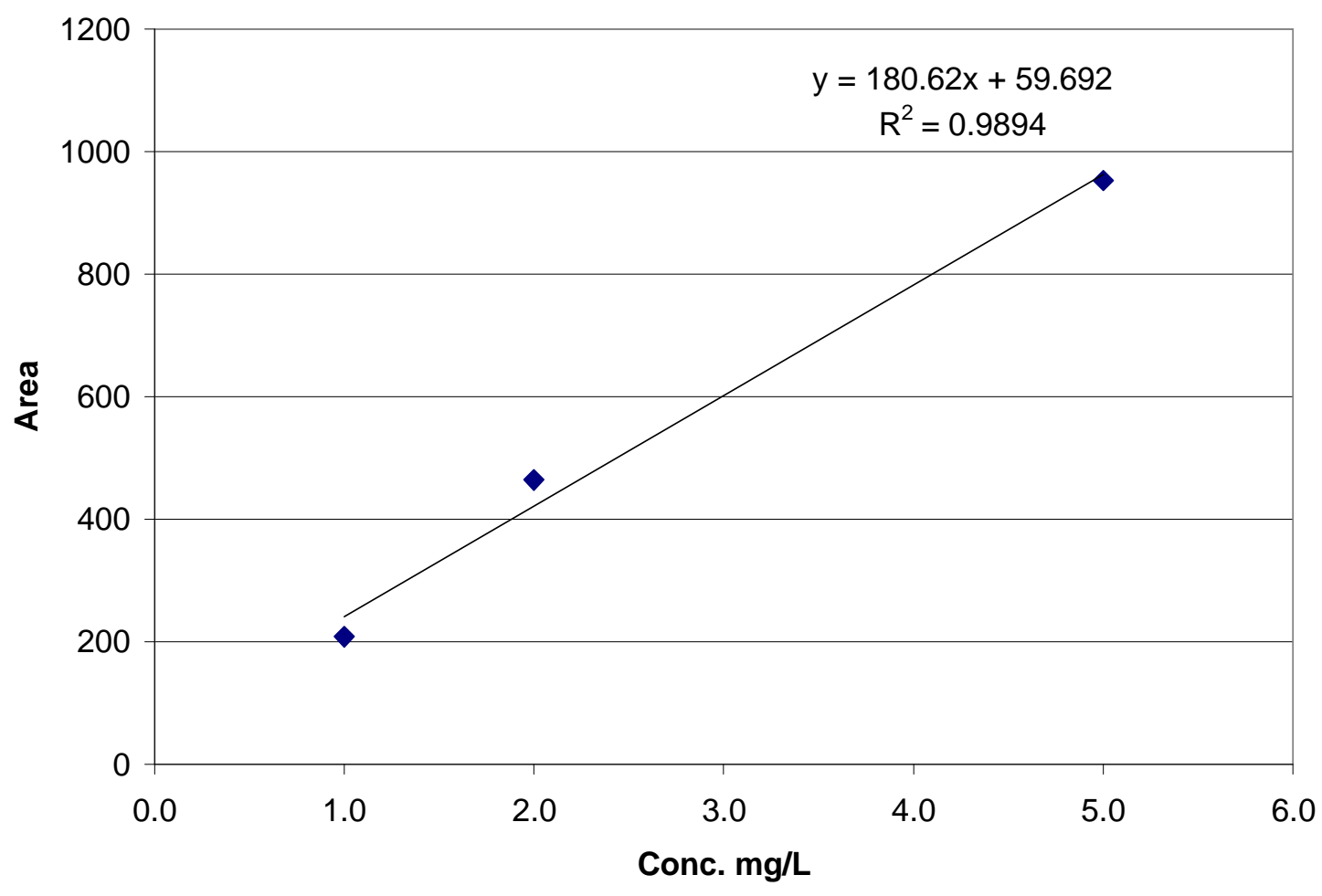

Figure 7-Standards Prepared in the Shielded Cell

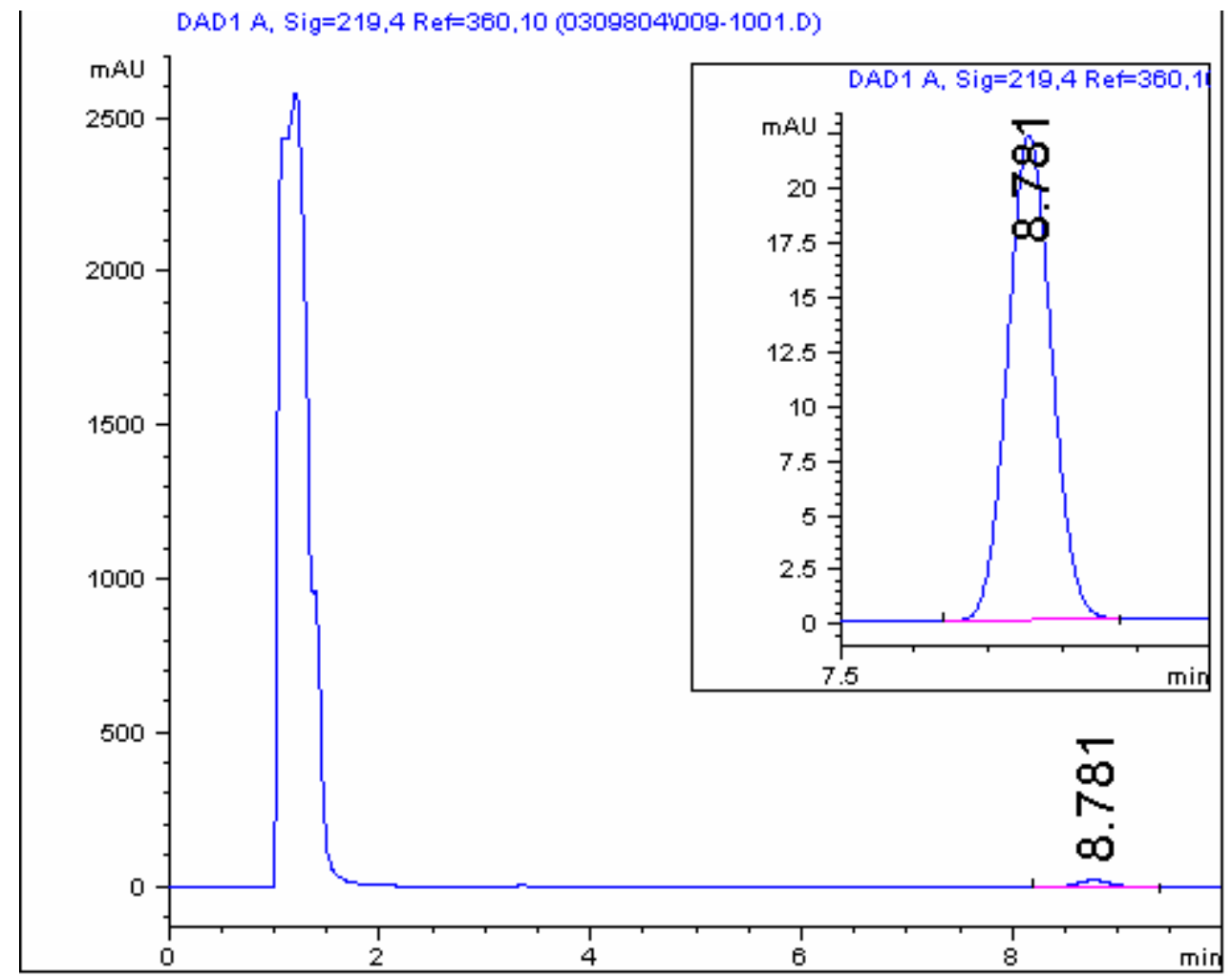

Figure 8-TPB Chromatogram: 1=Salt peak at $1.2 \mathrm{~min}, 2=\mathrm{TPB}$ at $8.8 \mathrm{~min}$

Page 13 of 20 
WSRC-TR-2004-00157, REV. 0

\subsection{GAMMA ANALYSIS OF EXTRACTION LAYERS}

Table 15 contains the results of the analyses of the samples prepared as described in 3.3.3.

Table 15-Gamma Analysis of Top and Bottom Extraction Layers

\begin{tabular}{|c|c|c|c|}
\hline Layer & Radionuclide & Activity(DPM/-mL) & 1 Sigma \%Unc \\
\hline Bottom Aqueous-1 & Cs-137 & $9.82 \mathrm{E}+06$ & $1.91 \%$ \\
\hline Bottom Aqueous-2 & Cs-137 & $9.90 \mathrm{E}+06$ & $1.91 \%$ \\
\hline Top Organic-1 & Cs-137 & $5.01 \mathrm{E}+05$ & $1.44 \%$ \\
\hline Top Organic-2 & Cs-137 & $7.81 \mathrm{E}+05$ & $1.43 \%$ \\
\hline Shielded Cell Blank & Cs-137 & $6.17 \mathrm{E}+01$ & $15.66 \%$ \\
\hline
\end{tabular}

\subsection{ANALYSIS OF DATA}

Researchers examined filtration as a method of collecting and concentrating insoluble TPB from Tank $50 \mathrm{H}$ supernate. This method yielded poor recoveries and variable results with known concentrations of KTPB spiked into simulated waste. When investigators used a solvent extraction sample preparation method on similar samples the recoveries were excellent and repeatable. The solvent extraction method was also applied to Tank $50 \mathrm{H}$ solids in simulated waste, Tank $50 \mathrm{H}$ solids in a mixture of plant inhibited water and Tank $41 \mathrm{H}$ supernate, and spike TPB samples of plant inhibited water and Tank $41 \mathrm{H}$ supernate.

\subsection{FILTRATION TESTS}

Section 3.2 describes the preparation of four 5.6 M average salt solutions containing 0.6 $\mathrm{mg} / \mathrm{L}$ of TPB, $0.8 \mathrm{mg} / \mathrm{L}$ of TPB, $2.0 \mathrm{mg} / \mathrm{L}$ of TPB or $5.0 \mathrm{mg} / \mathrm{L}$ of TPB. Researchers added a nearly saturated $\left(\mathrm{S}=0.9 \mathrm{~g} / \mathrm{L}\right.$ at $0{ }^{\circ} \mathrm{C}$ ) solution of $0.5 \mathrm{M} \mathrm{CsNO}_{3}$ to the samples prior to filtration. The purpose of the spike was to precipitate any TPB that maybe in solution and to exchange with radioactive cesium bound to TPB in Tank $50 \mathrm{H}$ waste lowering the activity of the solids.

Table 10 in section 4.1 contains the results of the filtration test preformed in triplicate. Investigators designed the sample preparation method to concentrate the solids by five fold. The recoveries are low but do start to improve as the concentration of TPB increases. The samples containing the highest concentration of TPB resulted in the highest recoveries $(\sim 20 \%)$. When researchers filtered the mother liquor of one of these samples through a $0.05 \mathrm{~mm}$ filter, a trace amount of TPB was observed indicating some breakthrough had occurred. The loss of material maybe due in part to the small quantities $(<100 \mu \mathrm{g})$ we are trying to capture. Any slight loss of TPB mass to glassware, plastic, and washings will dramatically lower the final recovery of material. This result prompted researchers to examine solvent extraction as a sample preparation method. 
WSRC-TR-2004-00157, REV. 0

\subsection{SOLVENT EXTRACTION}

\subsubsection{Choice of Solvent}

Researchers examined solvents of increasing polarity in section 3.4 Table 8. Methylene chloride, toluene, and ethyl acetate are immiscible in water but KTPB is not appreciably soluble in these solvents. Acetone and acetonitrile readily dissolve KTPB but these solvents are miscible with water. Two layers will form with the organic layer resting on top if the ionic strength of the aqueous solution is sufficient. When using these solvents to extract high salt solutions, acetone does have a drawback. Acetone resting on top of 5.6 $\mathrm{M}$ average salt solution appears to undergo a reaction changing the color of the clear solution to yellow after a day and dark yellow after a week as in section 3.4 Figure 3 . The acetone probably undergoes an Aldol reaction which is known to occur with ketones and hydroxide base to form, in equilibrium, $\beta$-hydroxy ketones and $\alpha, \beta$-unsaturated ketones. The literature and prior site experience supports the use of acetonitrile. Solubility values are listed in Table $16^{12}$ for TPB; compounds are considered insoluble at $<0.1 \mathrm{~g} / \mathrm{L}$. Acetonitrile readily dissolves sodium, potassium, and cesium TPB. Acetonitrile is thus considered a suitable choice of solvent to extract TPB from tank waste high in ionic strength.

Table 16-Solubility (S) of TPB in g/L at $25^{\circ} \mathrm{C}$

\begin{tabular}{|c|c|c|c|c|}
\hline Solution & NaTPB & KTPB & CsTPB & AgTPB \\
\hline $\mathrm{H}_{2} \mathrm{O}$ & 325 & $6.44 \mathrm{E}-02$ & $1.27 \mathrm{E}-02$ & $1.07 \mathrm{E}-06$ \\
\hline $\mathrm{ACN}$ & $>10$ & 19.0 & 12.7 & $6.83 \mathrm{E}-02$ \\
\hline
\end{tabular}

Section 3.5 describes researchers measuring the height of acetonitrile on top of average salt solutions of different molar strengths. As the average salt solution becomes more dilute, the height of the top organic layer decreases until one reaches a salt concentration below $2 \mathrm{M}$ sodium where two layers do not form as shown in Table 9 and Figure 9. Sodium hydroxide or average salt solution will have to be added to samples of low ionic strength in order for extraction to occur. 
WSRC-TR-2004-00157, REV. 0

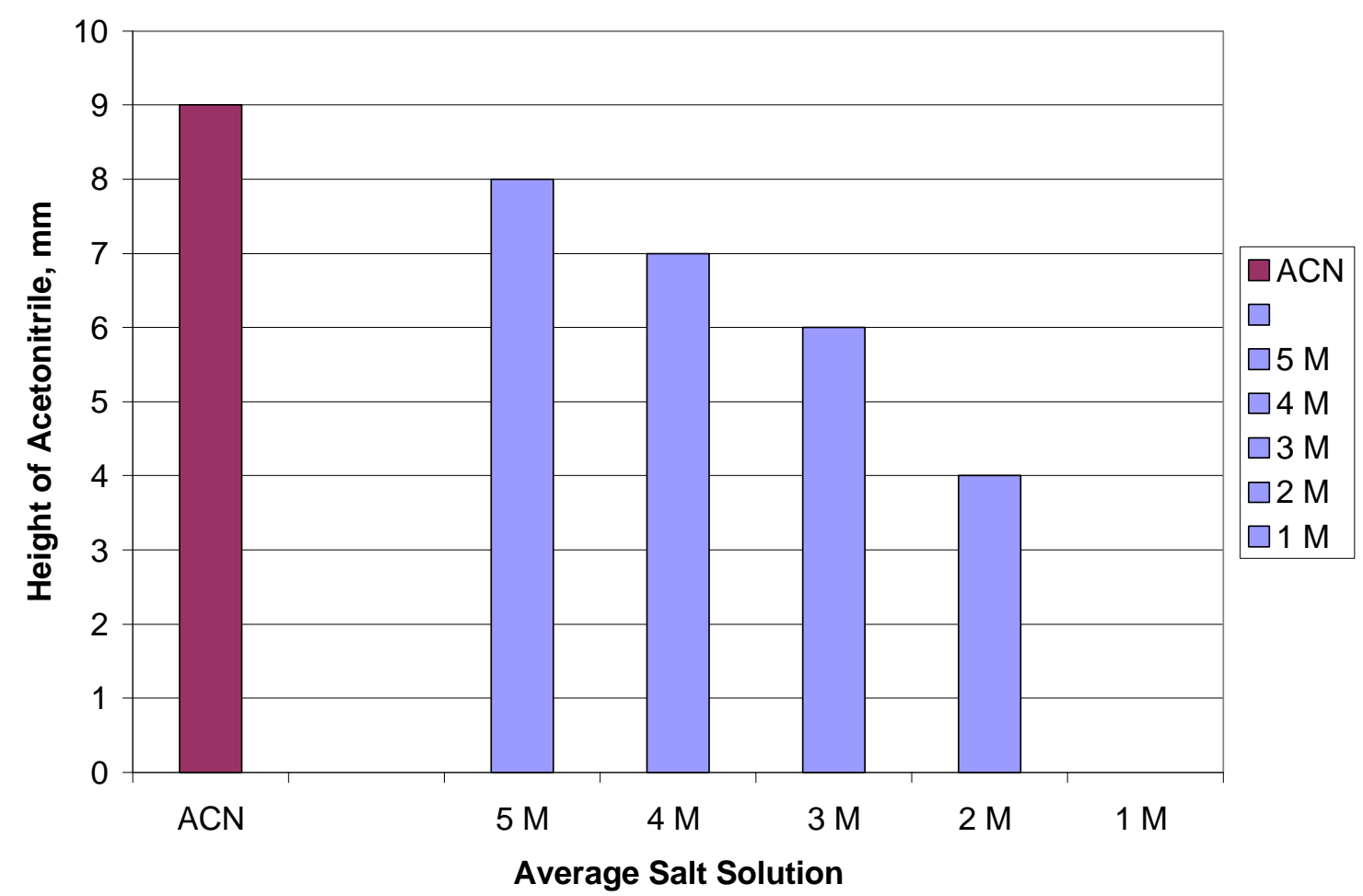

Figure 9-Acetonitrile (2.5 -mL) and Average Salt Solution (5.0-mL)

\subsubsection{TPB Spiked 5.6 M Average Salt Solution}

Section 3.3.1 describes the preparation and section 4.2.1 describes the experimental results of the simulated waste studies with TPB. Table 11 summarizes these results which were encouraging. All four concentration levels showed good recoveries (100-120\%) and reasonable RSD (\%) values ranging from 0.8 to 8.5 . The slightly elevated recoveries can be attributed to a decrease in the volume of acetonitrile because of its solubility in the salt solution as described in section 5.2.1. Figure 10 is a plot of the results that demonstrates linearity $\left(r^{2}=1\right)$. In the average salt solution, the spike concentrations of TPB were 0.5 $\mathrm{mg} / \mathrm{L}, 1.0 \mathrm{mg} / \mathrm{L}, 2.0 \mathrm{mg} / \mathrm{L}$, and $5.0 \mathrm{mg} / \mathrm{L}$. During the extraction process, there is a twofold concentration of the TPB analyte. The lowest concentration analyzed $(0.5 \mathrm{mg} / \mathrm{L}$ in average salt solution and $1.0 \mathrm{mg} / \mathrm{L}$ in acetonitrile) generated a strong peak on the chromatogram with a signal-to-noise $(\mathrm{S} / \mathrm{N})$ of 20 . Samples could be diluted one to one with average salt solution or to where the $\mathrm{S} / \mathrm{N}=10(0.25 \mathrm{mg} / \mathrm{L})$ and linearity would be maintained. 
WSRC-TR-2004-00157, REV. 0

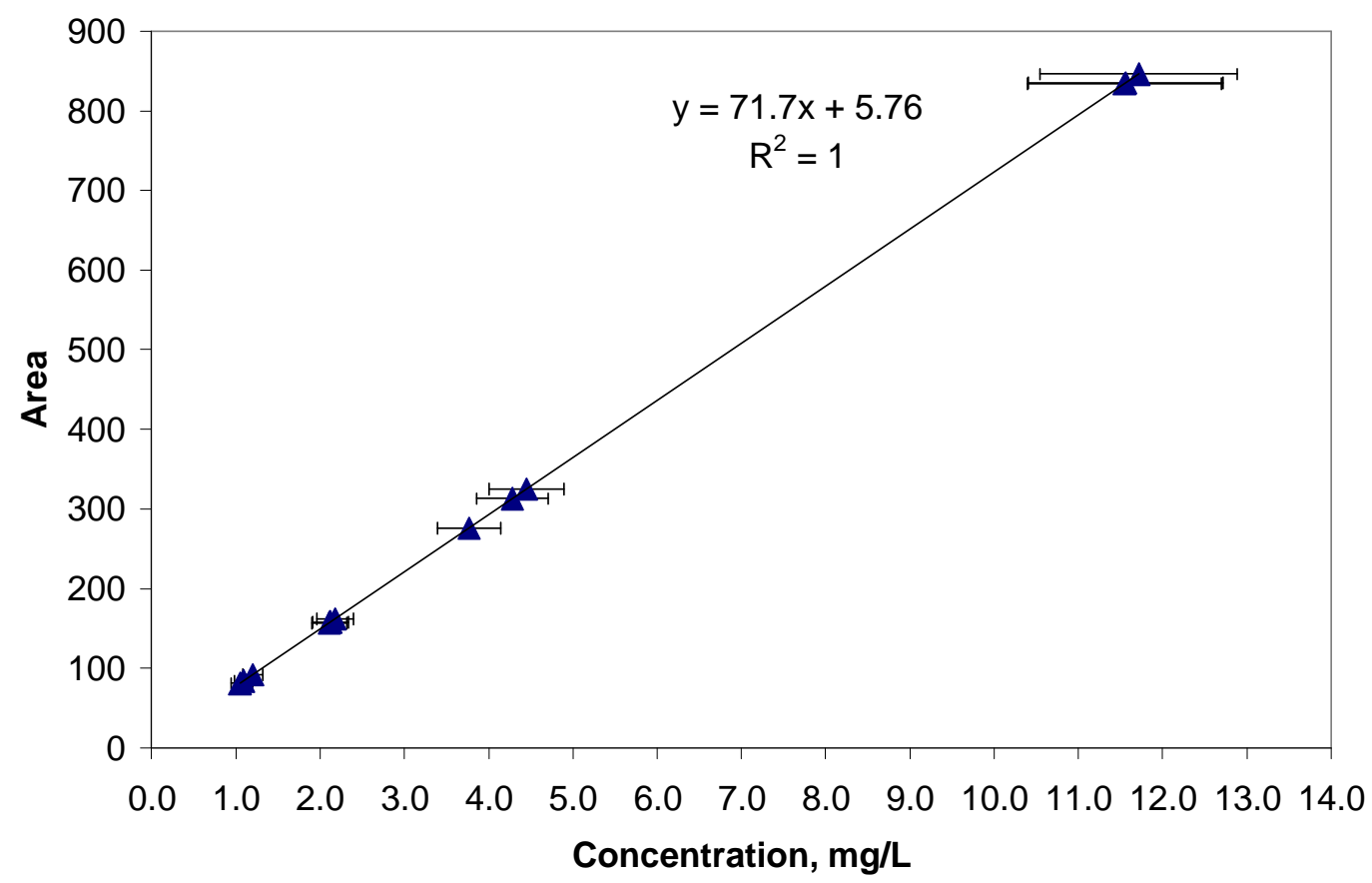

Figure 10-TPB Spiked into Average Salt Solution

\subsubsection{Tank 50H solids in Average Salt Solution}

Section 3.3.2 describes the preparation and section 4.2.2 describes the experimental results of the simulated waste studies with Tank $50 \mathrm{H}$ solids. Table 12 shows percent recoveries that are biased high (127\%-135\%) and a low value for the percent RSD of 0.4. The percent recoveries are based on a comparison of the extraction results to Tank $50 \mathrm{H}$ solids in acetonitrile analysis. The higher than expected recoveries are likely due to solubility of acetonitrile in the average salt solution and variability in the concentration of TPB in the starting Tank $50 \mathrm{H}$ solids.

\subsubsection{Tank 50H solids in Tank 41H supernate and PIW}

Section 3.3.3 describes the preparation and section 4.2.3 describes the experimental results of the Tank $41 \mathrm{H}$ supernate and PIW studies with Tank 50H solids. Similar to the simulated waste studies (5.2.3), Table 13 shows the percent recoveries are biased high because of the solubility of acetonitrile in average salt solution. The percent RSD is higher than the percent RSD obtain for the simulated waste study. This is not unexpected considering that some loss of precision can occur when moving from hands-on work to shielded cell work.

Table 7 shows the weights of the addition of Tank $41 \mathrm{H}$ supernate and acetonitrile to the samples. The percent RSD for the Tank $41 \mathrm{H}$ supernate is $\sim 2 \%$ and the acetonitrile is $\sim 3 \%$ which is elevated from the RSD of $\sim 1 \%$ achieved with hands-on work. Section 4.3 describes the experimental results of gamma analysis of the top and bottom layer of the 
extraction samples in duplicate. Table 15 contains the activity in the acetonitrile layer and demonstrates a decrease of activity of $94 \%$ and the $K_{D}=0.072$. The addition of nonradioactive $\mathrm{CsNO}_{3}$ to the samples seems to have contributed to the lowing of the activity in the acetonitrile layer by isotopic dilution. This result allowed for acetonitrile extracts from samples containing an approximate concentration of $0.3 \mathrm{Ci} / \mathrm{gal}$ cesium to be removed from the shielded cells and handled in a radiological hood without dilution. Without the decrease in activity, the reading of a $5.0-\mathrm{mL}$ aliquot was calculated to be 2.3 $\mathrm{mR} / \mathrm{hr}$ which is nearing the $5 \mathrm{mR} / \mathrm{hr}$ hood limit.

\subsubsection{TPB spiked Tank 41H supernate and PIW}

Section 3.3.4 describes the preparation and Section 4.2.4 describes the experimental results of the Tank $41 \mathrm{H}$ supernate and PIW spike with TPB. Researchers prepared three standards in Tank $41 \mathrm{H}$ supernate and PIW that accompanied the samples. Figure 7 is the calibration curve generated from the analysis of the standard extracts. Table 14 contains the sample analyses. The results show a similar percent RSD to the simulated waste study (5.2.2) and the percent recoveries $(100 \%, 101 \%$, and 114\%) are distributed around the concentration added.

\subsection{CONCLUSION}

Filtration as a means of concentrating TPB solids for analysis did not provide a reliable method. However, solvent extractions with acetonitile on high salt solutions does repeatably concentrate TPB in the organic layer. Tank waste samples need to have a high enough salt content for two layers to occur. With dilutions of $5.6 \mathrm{M}$ average salt solution, this has been shown to be at $2.0 \mathrm{M}$ or at higher salt content or ionic strength.

The authors met the technical task request of determining TPB at $0.8 \mathrm{mg} / \mathrm{L}$ in the presence of $0.38 \mathrm{Ci} / \mathrm{gal}$ of Cs- 137 with solvent extraction as the sample preparation method. The non radioactive $5.6 \mathrm{M}$ average salt solution samples demonstrated a limit of quantitation of $0.5 \mathrm{mg} / \mathrm{L}$ and a $\% \mathrm{RSD}$ of $7 \%$. The signal to noise $(\mathrm{S} / \mathrm{N}=20)$ of the 0.5 $\mathrm{mg} / \mathrm{L}$ peak indicated samples as low as $0.25 \mathrm{mg} / \mathrm{L}$ can be quantitated. The real waste tests where samples containing $0.3 \mathrm{Ci} / \mathrm{gal} \mathrm{Cs}-137$ were spiked with TPB in the range of 0.6 $\mathrm{mg} / \mathrm{L}$ to $5.0 \mathrm{mg} / \mathrm{L}$. Three unknown spikes at $2.0 \mathrm{mg} / \mathrm{L}$ yielded an average of $2.1 \mathrm{mg} / \mathrm{L}$ with a $\%$ RSD of $7 \%$ and a one sigma percent uncertainty ( $\sigma \%$ unc) of $15 \%$.

The ionic strength of the Tank $48 \mathrm{H}$ waste (i.e., $\sim 2.9 \mathrm{M}$ ) approaches the lower end of the recommended range for the sample pretreatment method. Some treatment options for the waste will result in further dilution. Hence, phase separation may prove less efficient for this matrix. The Tank $48 \mathrm{H}$ waste also contains solids in the form of monosodium titanate and sludge. These solids will impact the efficiency and the difficulty of phase separation during the organic extraction step in the sample preparation. The exact impact can only be determined through additional testing. While the exact conditions may prove more favorable when the final flowsheet evolves, these combined factors suggest potential poorer performance for Tank $48 \mathrm{H}$ samples of relevance. Therefore, we recommend that the Tank $48 \mathrm{H}$ project fund scouting measurements to determine the quantitation limit for TPB and other TPB decomposition products in the Tank $48 \mathrm{H}$ waste. 


\subsection{QUALITY CONTROL}

This study fulfills the activity defined in Technical Task Request SP-TTR-2003-00060. Data obtained from this study resides as records in WSRC-NB-2003-00162.

\subsection{ACKNOWLEGEMENTS}

The authors would like to thank Sharon Smith, Betty Croy, Annie Still, Mona Blume and Vikki Dukes for performing much of the hands on work and the dedicated Shielded Cells Technicians, Martha Holmes and Dennis Lewis for preparing samples in the shielded cells.

The authors would also like to thank David DiPrete, Ceci DiPrete and their staff for rapid gamma analysis and Dan Mccabe and Chris Martino for fruitful suggestions. 
WSRC-TR-2004-00157, REV. 0

\subsection{REFERENCE}

1 C. J. Martino, "Initial Results of the Tank 41H C1/C3-Riser Supernate Sample Analysis", SRT-LWP-2003-00096, November 04, 2003.

2 C. D. Banaszewski, "Engineering Path Forward HTF-PF-2002-0014: Tank 50 Solids", HLW-STE-2002-00388, October 23, 2002.

${ }^{3}$ W. R. Wilmarth, "Results of Sample Analysis from Solids Removed from Tank 50H", WSRC-TR-2002-00506, November 1, 2002.

${ }^{4}$ C. D. Banaszewski, "Tank 50 Solids Mound Volume Calculation", J-CLC-H-00793, Rev. 0, November 2002.

5 J. M. Russell, "Tank Farm Allowable TPB Heel Determination", X-CLC-H-00495, Rev. 0, April 05, 2004.

6 D. P. Lambert, T. B. Peters, M. E. Stallings, and S. D. Fink, "Analysis of Tank 48H Samples HTF-E-03-73 (June 03, 2003) and HTF-E-03-127 (September 17, 2003) WSRC-TR-2003-00720, January 20, 2004.

7 “Tank Farm Allowable TPB Heel Determination,” X-CLC-H-00495, March 2004.

10 D.D Walker "Preparation of Simulated Waste Solutions", WSRC-TR-99-00116, March 15, 1999.

11 C. J. Martino, "Initial Results of the Tank 41H C1/C3-Riser Supernate Sample Analysis", HLW-STE-2002-00388, October 23, 2002.

12 O. Popovych. Solubility Data Series. Vol. 18, p 3, Pergamon Press Ltd., New York (1981).

Page 20 of 20 